Article

\title{
Hydrological Guidelines for Reservoir Operation to Enhance Water Governance: Application to the Brazilian Semiarid Region
}

\author{
José Carlos de Araújo ${ }^{1, * \mathbb{C}}$, George Leite Mamede ${ }^{2}$ and Berthyer Peixoto de Lima ${ }^{3}$ \\ 1 Department of Agricultural Engineering, Federal University of Ceará, Fortaleza CEP 60455-900, CE, Brazil \\ 2 Institute for Engineering and Sustainable Development, University of International Afro-Brazilian \\ Integration, UNILAB, Redenção CEP 62790-000, CE, Brazil; georgemamede@hotmail.com \\ 3 COGERH, Water Resources State Company, Fortaleza CEP 60824-140, CE, Brazil; berthyer@gmail.com \\ * Correspondence: jcaraujo@ufc.br; Tel.: +55-85-3366-9754
}

Received: 12 October 2018; Accepted: 8 November 2018; Published: 12 November 2018

\begin{abstract}
The Brazilian water legislation advocates that some uses have priority over others, but this aspect has never been clearly addressed, generating conflicts. Water authorities usually refer to hydrological models to justify their decisions on water allocation. However, a significant group of stakeholders does not feel qualified to discuss these models and is excluded from the decision process. We hereby propose a hydrologically robust method to correlate water uses with their respective reservoir alert volumes, which should empower the less formally educated stakeholders. The method consists of: (i) generating the water yield versus reliability curve, using a stochastic approach; (ii) generating the yield versus alert volume family of curves, using a water-balance approach; (iii) calibrating the key parameter $\mathrm{T}$ (depletion duration) using field data; and (iv) associating each water use with its alert volume. We have applied the method to four of the largest reservoirs $\left(2 \times 10^{3}-2 \times 10^{2} \mathrm{hm}^{3}\right)$ in the semi-arid Ceará State. The results indicate that low-priority water uses should be rationalized when the reservoir volume is below $20 \%$, whereas uses with very high priority should start rationalization when it is below $11 \%$. These hydrological guidelines should help enhance water governance among non-specialist stakeholders in water-scarce and reservoir-dependent regions.
\end{abstract}

Keywords: reservoirs; water allocation; water scarcity; alert volume; governance

\section{Introduction}

The northeast of Brazil, where the semiarid Caatinga biome prevails, is home to 25 million inhabitants with high water demand. Its rivers, however, are intermittent and groundwater is limited and often salty [1]. To cope with the frequent and severe droughts, the water-supply policy strongly relies on artificial surface reservoirs [2,3], whose poor management may negatively affect the most vulnerable fraction of the population [4]. During the recurrent water-scarce periods, when societal conflicts arise, efficient operation rules for multiple uses-a requisite for efficient reservoir water allocation-become a great challenge [5-12]. The Brazilian respective water legislation [13] advocates that under scarcity some uses (e.g., human and animal provision) should be prioritized. Although the law is over two decades old, a clear supply prioritization has not yet taken place, and this generates serious conflicts among water users. In the region, except for a small number of cases, there is no hydropower production. The main conflicts, which refer to water release for the diffuse demands of thousands of farms, municipalities and few industries, occur during the droughts. Because of their frequency, the problem becomes more complex: the available water is not enough to supply even 
the minimum requirements of some sectors. In 2012, for example, there was the onset of a severe multi-annual drought in the semiarid State of Ceará [14]. During the second year of drought, the irrigation users stopped receiving water from the reservoirs not only for production, but also to keep trees alive. Contrastingly, industrial users have been uninterruptedly supplied up to the moment [15]. The priority criteria used for these decisions were not clearly justified.

In Brazil, water allocation is a participatory process coordinated by River Basin Committees, which are composed by stakeholders among public authorities, civil society and water users. During water-scarcity periods, the Water Agency is allowed to restrain supply, either partially or totally. In these periods, authorities usually justify their decisions citing the results of operational hydrological models. Reservoir operation rules are commonly based on hydrological available information $[6,9]$ of long-term water storage and are lengthily maintained as once defined [16,17]. Several water allocation models have been developed in the last decades, e.g., AQUATOOL [18], ACQUANET [19], RIVERWARE—River and Reservoir Modeling Tool [20], MODSIM-Decision Support System for Integrated River Basin Management [21], ILMP-Interval Linear Multi-Objective Programming Model [22], and the Bellman SDP—Stochastic Dynamic Programming [9]. However, among the committee members, there is a significant group that does not feel qualified to discuss such models and, therefore, is excluded from the decision process. Technocracy then defeats democracy, with biased losses for the peasants, who are poorer and less formally educated. They are, nevertheless, able to interpret the degree of water availability—especially during droughts [10]—using the stored water volume in the reservoirs [23]. We understand that the participatory approach $[24,25]$ is the only solution to make such a complex system run efficiently, however, each stakeholder must be thoroughly informed to take the best decision. Thus, to guarantee proper governance of water allocation, guidelines based on the reservoir volume, which can be understood by all stakeholders, are certainly preferable to technocratic strategies. We hereby aim at proposing a hydrologically robust method that produces simple outputs, which correlate each water use with its respective alert volume. In this context, the alert volume is the stored volume that triggers water rationalization due to quantitative shortage. The four-step method, which uses the reservoir volume as the key variable, considers water balance in the reservoir, climate and hydrological variability, morphological features of the reservoir and historically released discharges. We have applied the method to four of the largest reservoirs $\left(2 \times 10^{2}-2 \times 10^{3} \mathrm{hm}^{3}\right)$ of the State of Ceará.

\section{Materials and Methods}

\subsection{Study Area}

The method was applied to four reservoirs, all located in the Caatinga biome (Figure 1), where annual rainfall is moderate $\left(500-850 \mathrm{~mm} \cdot \mathrm{year}^{-1}\right)$, potential evaporation is high $\left(2000-2600 \mathrm{~mm} \cdot \mathrm{year}^{-1}\right)$, groundwater is limited and salty due to a prevailing crystalline basement, rivers are intermittent, runoff is low (10-70 $\mathrm{mm} \cdot$ year $\left.^{-1}\right)$ and droughts are recurrent [14]. The rainy season (January to June) encompasses almost $90 \%$ of the annual rainfall and almost $100 \%$ of the runoff, whereas the reservoirs suffer depletion in the long dry season (July to December), sometimes drying out completely [26]. The natural hydrological system constantly fails to provide enough water for that densely populated environment, which called for the construction of a reservoir-based water system [2,3]. Due to the considerable meteorological inter- and intra-annual variability, the high number of reservoirs (one dam every $5 \mathrm{~km}^{2}$ on average), and the high residence time of the waters within the reservoirs (which causes low levels of water quality [27]), the Caatinga biome has become a challenging biome for water management [28]. Usually, River Basin Committees decide on water release shortly after the rainy season, the key information being the stored reservoir volume. The committee stakeholders use their empirical knowledge to adjust their demands to the operational water availability, taking into consideration the risk of water scarcity in the coming years. The main hydrological features of the focus reservoirs (Orós, Araras, Pentecoste, and Aracoiaba) are presented in Table 1. 
Table 1. Main variables of the four focus reservoirs. the data for each field represent a pair, composed of the measured released discharge and the respective reservoir volume on the same day.

\begin{tabular}{|c|c|c|c|c|c|}
\hline Variables & Orós & Araras & Pentecoste & Aracoiaba & Average \\
\hline Storage capacity $\left(\mathrm{hm}^{3}\right)$ & 1940 & 891 & 360 & 162 & 838 \\
\hline Catchment area $\left(\mathrm{km}^{2}\right)$ & 24,600 & 3520 & 2840 & 533 & 7873 \\
\hline Annual rainfall (mm) & 529 & 759 & 702 & 828 & $575^{\text {(c) }}$ \\
\hline Average inflow $\left(\mathrm{hm}^{3} \cdot\right.$ year $\left.^{-1}\right)$ & 1505 & 608 & 183 & 68 & $1261^{(\mathrm{c})}$ \\
\hline Storage capacity/average inflow (year) & 1.29 & 1.47 & 1.97 & 2.38 & $1.39^{(c)}$ \\
\hline Coefficient of variation of inflow (n.d.) & 0.9 & 1.2 & 1.0 & 0.6 & $0.9^{(c)}$ \\
\hline$Q_{90} /$ average inflow (n.d.) ${ }^{(a)}$ & 0.43 & 0.38 & 0.35 & 0.76 & $0.42^{(\mathrm{c})}$ \\
\hline Field data sample size & 250 & 147 & 135 & 26 & 140 \\
\hline Field data sampling period (years) & 22 & 20 & 19 & 14 & 19 \\
\hline First sampling year & 1996 & 1996 & 1996 & 2003 & \\
\hline Last sampling year & 2017 & 2015 & 2014 & 2016 & \\
\hline Calibrated depletion duration $\mathrm{T}$ (months) ${ }^{(\mathrm{b})}$ & 5.7 & 6.0 & 5.8 & 6.0 & 5.9 \\
\hline Number of outliers for $\mathrm{T}=6$ months & 1 & 0 & 1 & 0 & 0.5 \\
\hline
\end{tabular}

(a) $\mathrm{Q}_{90}$, water yield with $90 \%$ annual reliability, (n.d.) means non-dimensional; ${ }^{(b)}$ obtained by solving Equation (7), assuming that the parameters $Q_{i}=0$ and $V_{f}=0$; (c) average weighted with respect to the catchment area.
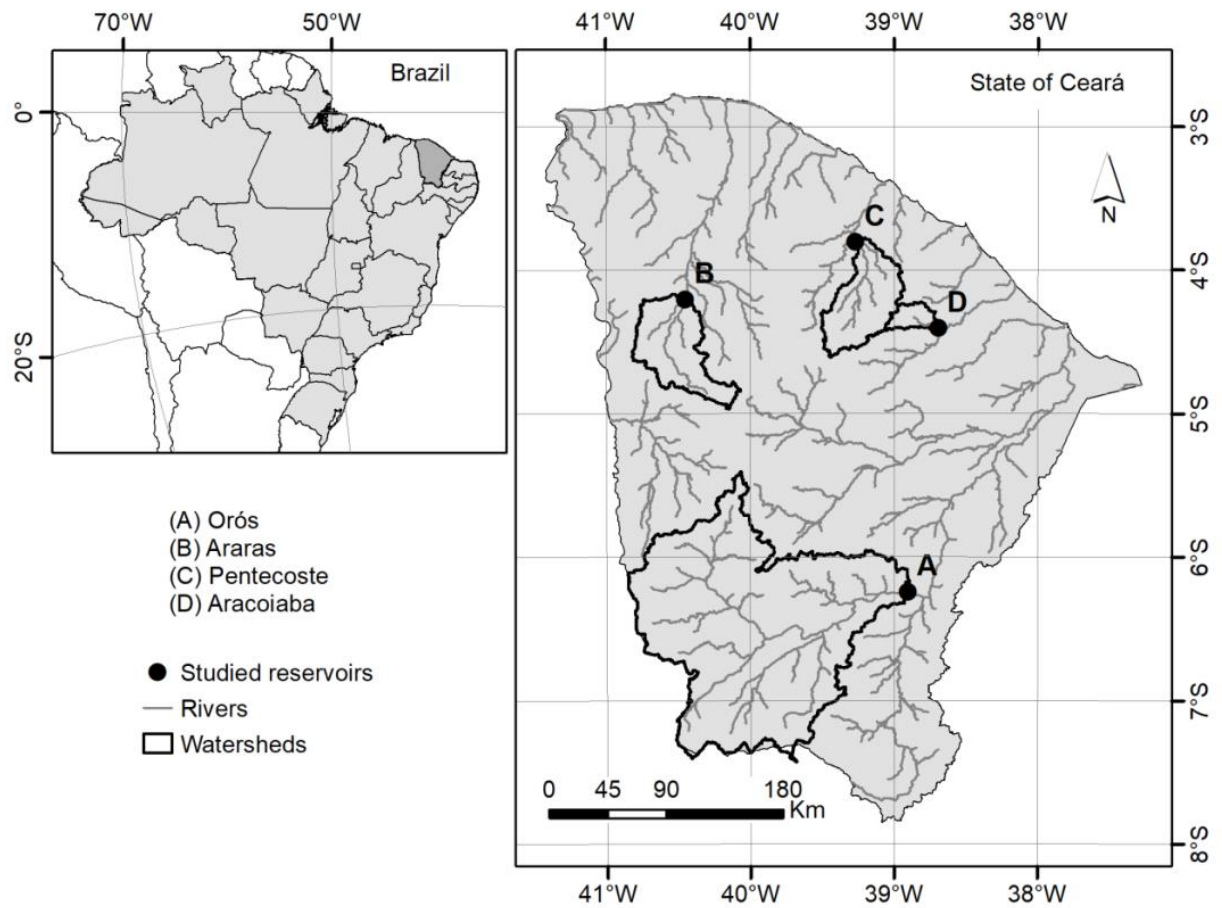

Figure 1. Location of the State of Ceará, Brazil, the study reservoirs, and their respective catchment areas.

\subsection{Synthesis of the Proposed Method and Data Sources}

Figure 2 presents a synthesis of the proposed method. Initially, there is the preparatory phase, in which the stakeholders, during a Basin Committee meeting, define the clusters of water uses, and associate each one with a priority level and its respective degree of reliability. The preparatory phase is supposed to be outlined within the River Basin Committee, using a participatory approach. After the rainy season, there is a general meeting with representatives of all sectors from the basin (society, government, and stakeholders) to decide, among others, on the reservoir operation during the following dry season. After the discussion, the representatives vote and this decision is followed by the water agency. In fact, within two decades, the effectively released discharges differed only $10 \%$ from those voted in the general meetings [14]. In Phase I, the main goal is to establish the relation 
between the withdrawal discharge from the reservoir and its respective reliability. In Phase II, reservoir depletion during the dry season is simulated, generating a family of curves. The key parameter for each curve is T (depletion duration). The objective of Phase III is to calibrate the parameter T, establishing the function between a possible maximum withdrawal discharge and the effectively stored volume. The last step, Phase IV, is meant to associate each water use (and, therefore, its degree of reliability) to the respective alert volume and its withdrawal discharge. The output table generates reference values, which are to be validated or modified by the committees. The hydrological data were obtained in [29] and the specific dam data were retrieved from $[14,30]$.

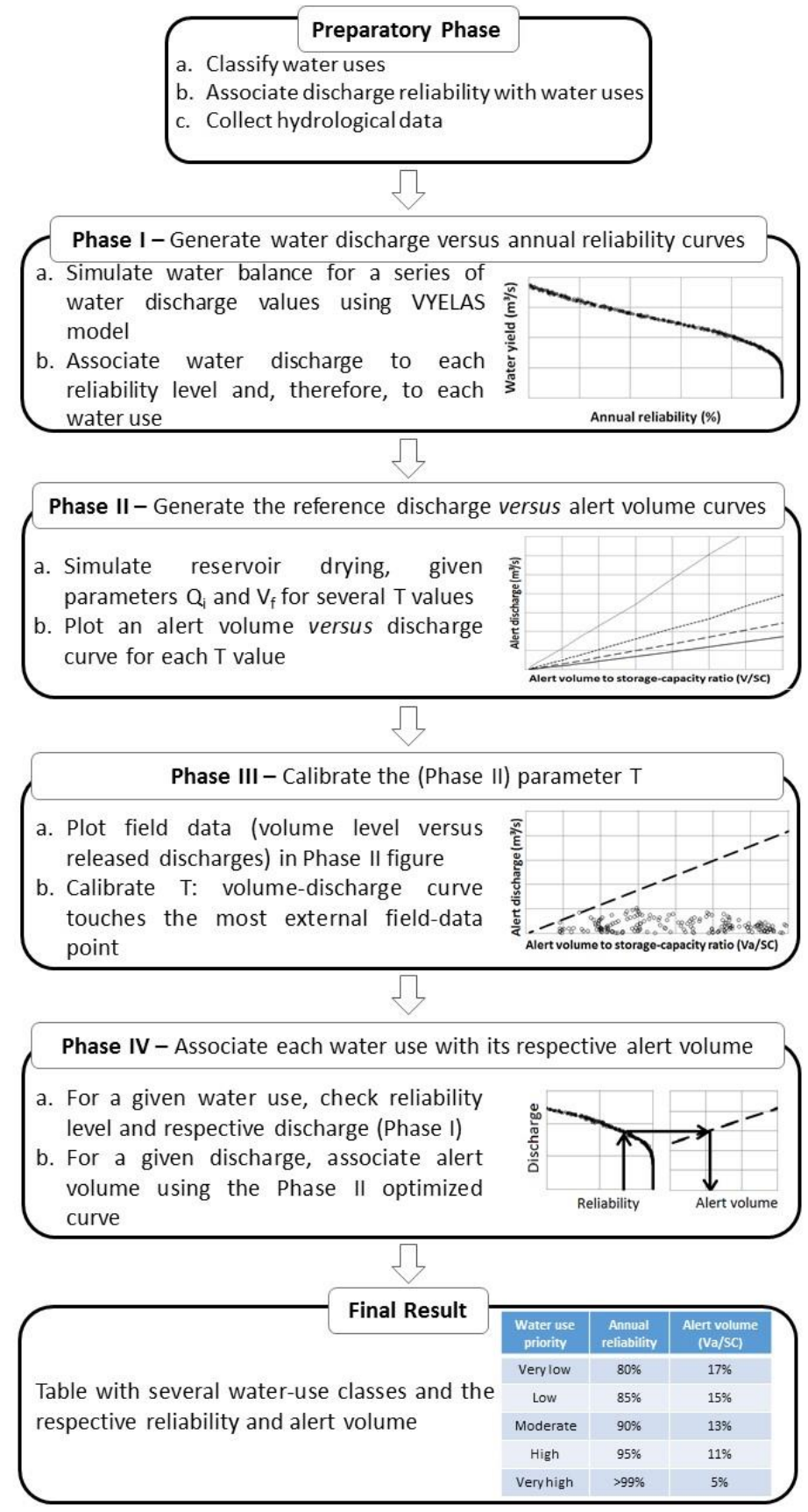

Figure 2. Flow chart of the proposed methodology. $\mathrm{Q}_{\mathrm{i}}$ means input discharge, $\mathrm{V}_{\mathrm{f}}$ is the final reservoir volume after depletion, and $\mathrm{T}$ is the depletion duration. 


\subsection{Phase I: Withdrawal Discharge as a Function of Annual Reliability}

We used the VYELAS (Volume-Yield Elasticity) model to calculate the annual reliability of a given withdrawal discharge $\left(\mathrm{Q}_{\mathrm{W}}\right.$, or water yield) of surface reservoirs [31]. It establishes the water balance (Equations (1) and (2)) at monthly time steps using long synthetic series to compute the annual reliability (G, Equation (3)) of a given withdrawal discharge [32]. The model considers the operational rules as executed by the River Basin Committees in the Semi-arid [14], and implicitly solves the simultaneous processes of evaporation, infiltration and withdrawal during the dry season.

$$
\frac{\mathrm{dV}(\mathrm{t})}{\mathrm{dt}}=\left(\mathrm{Q}_{\mathrm{H}}+\mathrm{Q}_{\mathrm{R}}+\mathrm{Q}_{\mathrm{G}}+\mathrm{Q}_{\mathrm{imp}}\right)-\left(\mathrm{Q}_{\mathrm{W}}+\mathrm{Q}_{\mathrm{E}}+\mathrm{Q}_{\mathrm{inf}}+\mathrm{Q}_{\mathrm{O}}+\mathrm{Q}_{\mathrm{exp}}\right)=\Delta \mathrm{Q}(\mathrm{t})
$$

In Equation (1), $\mathrm{V}(\mathrm{t})$ is the effectively stored reservoir volume at time $\mathrm{t} ; \mathrm{Q}_{\mathrm{H}}$ is the discharge of the direct precipitation over the lake; $Q_{R}$ is the inflow discharge from the rivers; $Q_{G}$ is the inflow discharge from the groundwater; $Q_{i m p}$ is the eventual import discharge from another basin by transfer structures; $\mathrm{Q}_{W}$ is the withdrawal discharge; $\mathrm{Q}_{\mathrm{E}}$ is the evaporation discharge; $\mathrm{Q}_{\text {inf }}$ is the infiltration discharge; $\mathrm{Q}_{\mathrm{O}}$ is the overflow discharge through the outlet; and $\mathrm{Q}_{\exp }$ is the eventual export discharge to another basin by transfer structures. Field measurements in the Brazilian Semi-arid region have shown that, in most cases, the difference $\left(Q_{H}+Q_{G}\right)-\left(Q_{E W}+Q_{\text {inf }}\right)$ is negligible on a monthly time scale $[29,30]$. The term $Q_{E W}$ represents the evaporation discharge of the wet season, and the annual evaporation discharge is constituted by $Q_{E}=Q_{E W}+Q_{E D}$, where $Q_{E D}$ is the evaporation in the dry season. Equation (1) turns into Equation (2), which is used in the VYELAS model. For the reservoirs of this research, note that $\mathrm{Q}_{\mathrm{imp}}=\mathrm{Q}_{\exp }=0$.

$$
\begin{gathered}
\frac{\mathrm{dV}(\mathrm{t})}{\mathrm{dt}} \approx\left(\mathrm{Q}_{\mathrm{R}}+\mathrm{Q}_{\mathrm{imp}}\right)-\left(\mathrm{Q}_{\mathrm{W}}+\mathrm{Q}_{\mathrm{ED}}+\mathrm{Q}_{\mathrm{O}}+\mathrm{Q}_{\mathrm{exp}}\right) \\
\mathrm{G}=\frac{\mathrm{N}_{\mathrm{S}}}{\mathrm{N}_{\mathrm{S}}+\mathrm{N}_{\mathrm{NS}}}
\end{gathered}
$$

In Equation (3), $G$ is the annual reliability for long series, $N_{S}$ is the number of successful years, whereas $\mathrm{N}_{\mathrm{NS}}$ is the number of unsuccessful years in the simulation. In this context, a successful year is one in which the planned water demand can be integrally met without constraint, i.e., not leading to the reservoir level be below alert volume. We fixed a withdrawal discharge and simulated the reservoir operation 10,000 times (each simulation referred to a whole year), as recommended by Campos [32] for basins whose annual inflow coefficient of variation is close to 1 , as in the studied basins. For each discharge, we computed the reliability G using Equation (3). Then, we fixed another discharge and restarted the simulation procedure, yielding the "discharge versus reliability" curve, as in [14,31,32].

\subsection{Phase II: Reference Discharge Versus Alert Volume Family of Curves}

The joint application of Equations (4)-(6) yields Equation (7).

$$
\begin{gathered}
\int_{\mathrm{V}_{0}}^{\mathrm{V}_{\mathrm{f}}} \mathrm{dV}=\int_{0}^{\mathrm{T}} \Delta \mathrm{Q}(\mathrm{t}) \cdot \mathrm{dt} \\
\mathrm{Q}_{\mathrm{i}}=\mathrm{Q}_{\mathrm{H}}+\mathrm{Q}_{\mathrm{R}} \\
\delta \mathrm{Q}=\mathrm{Q}_{\mathrm{inf}}-\mathrm{Q}_{\mathrm{G}}=\varphi \cdot \mathrm{E}_{\mathrm{A}} \cdot \mathrm{A} \\
\mathrm{V}_{\mathrm{f}}=\mathrm{V}_{0}+\int_{0}^{\mathrm{T}}\left[\mathrm{Q}_{\mathrm{i}}+\mathrm{Q}_{\text {imp }}-\left(\mathrm{Q}_{\mathrm{W}}+\mathrm{Q}_{\mathrm{E}}+\mathrm{Q}_{\mathrm{O}}+\delta \mathrm{Q}+\mathrm{Q}_{\exp }\right)\right] \cdot \mathrm{dt}
\end{gathered}
$$

In Equations (4)-(7), $\mathrm{t}$ is time; $\mathrm{V}_{0}$ is the reservoir volume in the beginning of the dry season; $\mathrm{V}_{\mathrm{f}}$ is the reservoir volume after the simulated depletion; $T$ is the depletion duration; $Q_{i}$ is the input discharge; $\delta \mathrm{Q}$ is the difference between infiltration and groundwater discharges; $\mathrm{E}_{\mathrm{A}}$ is the evaporation rate; $\mathrm{A}$ is the effectively flooded area of the reservoir; and $\varphi$ is a parameter. According to Mamede et al. [2], $\varphi$ equals 0.30 for a long-term balance in the Brazilian Semiarid. In the dry season, for a given reservoir 
volume $\left(\mathrm{V}_{0}\right)$, there is a withdrawal discharge $\left(\mathrm{Q}_{\mathrm{W}}\right)$ that depletes the reservoir to volume $\mathrm{V}_{\mathrm{f}}$ at duration $T$, given the input discharge $Q_{i}$. The withdrawal discharge $Q_{W}$ is calibrated regarding the objective function ( $\psi$ : Equation (8)), which should yield a value as close to zero as possible when solving Equation (7). The same procedure is repeated for varying initial volumes $V_{0}$ and $T$, delivering a family of curves of $Q_{W}\left(V_{0}, T\right)$, for the given parameters $Q_{i}$ and $V_{f}$. Each point of a "discharge versus alert volume" curve, therefore, correlates the withdrawal discharge (ordinate) that can be taken from the reservoir when the water storage equals the volume (abscissa); thus, after time $\mathrm{T}$, the final storage equals $V_{f}$.

$$
\psi=\mathrm{V}\left(\mathrm{V}_{0}, \mathrm{~T}, \mathrm{Q}_{\mathrm{W}}, \mathrm{Q}_{\mathrm{i}}\right)-\mathrm{V}_{\mathrm{f}}
$$

The three parameters $\left(\mathrm{Q}_{\mathrm{i}}, \mathrm{V}_{\mathrm{f}}\right.$, and $\left.\mathrm{T}\right)$ must be established. The model user elects two of them $\left(\mathrm{Q}_{\mathrm{i}}\right.$ and $\mathrm{V}_{\mathrm{f}}$, for example) and calibrate the third ( $\mathrm{T}$, in this case) during Phase III. In the study region, the water drawdown during the dry season is caused by simultaneous evaporation, infiltration and withdrawal, whereas the rainfall and runoff contribution is negligible $[3,29]$. Therefore, in the simulations of the present research, we assumed that no input discharge occurred $\left(Q_{i}=0\right)$ and that the reservoir dried out $\left(\mathrm{V}_{\mathrm{f}}=0\right)$ after the duration $\mathrm{T}$. Since no inflow was assumed, no overflow discharge through the outlet was expected either $\left(\mathrm{Q}_{\mathrm{O}}=0\right)$.

\subsection{Phase III: Calibration of The Parameter $T$}

The curves generated by Equation (7) were confronted with the field data (points), which consisted of pairs of actually released discharges $\left(\mathrm{Q}_{\mathrm{W}}(\mathrm{t})\right)$, associated with the reservoir volumes $(\mathrm{V}(\mathrm{t}))$ on the same day that $\mathrm{Q}_{\mathrm{W}}$ was first released in the field, based on a committee decision. In the operation process, the water authorities may change the release depending on the circumstances, such as the variation of the demand. We have collected all available field data [30] that associate the reservoir volume with the respective released discharge. Hence, each datum corresponds to a point in the graphic. The calibrated $\mathrm{T}$ value is the one whose curve is tangent to the most external field-data point, which represents the highest-risk water release. It is important to observe that field data are only meaningful if the decision on water release is based on a valid criterion (a collective decision of the basin committee, for example), i.e., if the reservoir operation is acceptable to society. Otherwise, the data are not representative of the legitimate will of the users and should be discarded. The key output of Phase III is, thus, one curve that relates reference discharge to alert volume.

\subsection{Phase IV: Association of Each Water Use with Its Respective Alert Volume}

For the water committee, each water use must be associated with a priority category (e.g., very low, low, moderate, high and very high) and, therefore, with the respective reliability level. Based on the result of Phase I, the stakeholders can compute the withdrawal discharge as a function of its respective reliability level. Subsequently, based on the result of Phases II and III, they can assess the alert volume as a function of the withdrawal discharge. At the end of Phase IV, there is a direct association between each water use and its respective alert volume. This means that, when the reservoir reaches alert volume, the respective users must start rationing water. This output, although based on a robust hydrological analysis, is simple and refers directly to the key decision variable of the stakeholders: the effective reservoir volume.

\section{Results}

\subsection{Discharges as a Function of the Annual Reliability Level}

Figure 3 depicts the monotonically-decreasing relation among withdrawal discharges with their respective annual reliability for the investigated reservoirs. It is also noteworthy that model sensitivity increases particularly in a region of high reliability $(90-100 \%)$. The derivative $\mathrm{dQ}_{\mathrm{W}} / \mathrm{d}_{\mathrm{G}}$ in the vicinity of $\mathrm{G}=100 \%$, for example, is almost five times higher than that of the $\mathrm{G}=80 \%$ vicinity. 

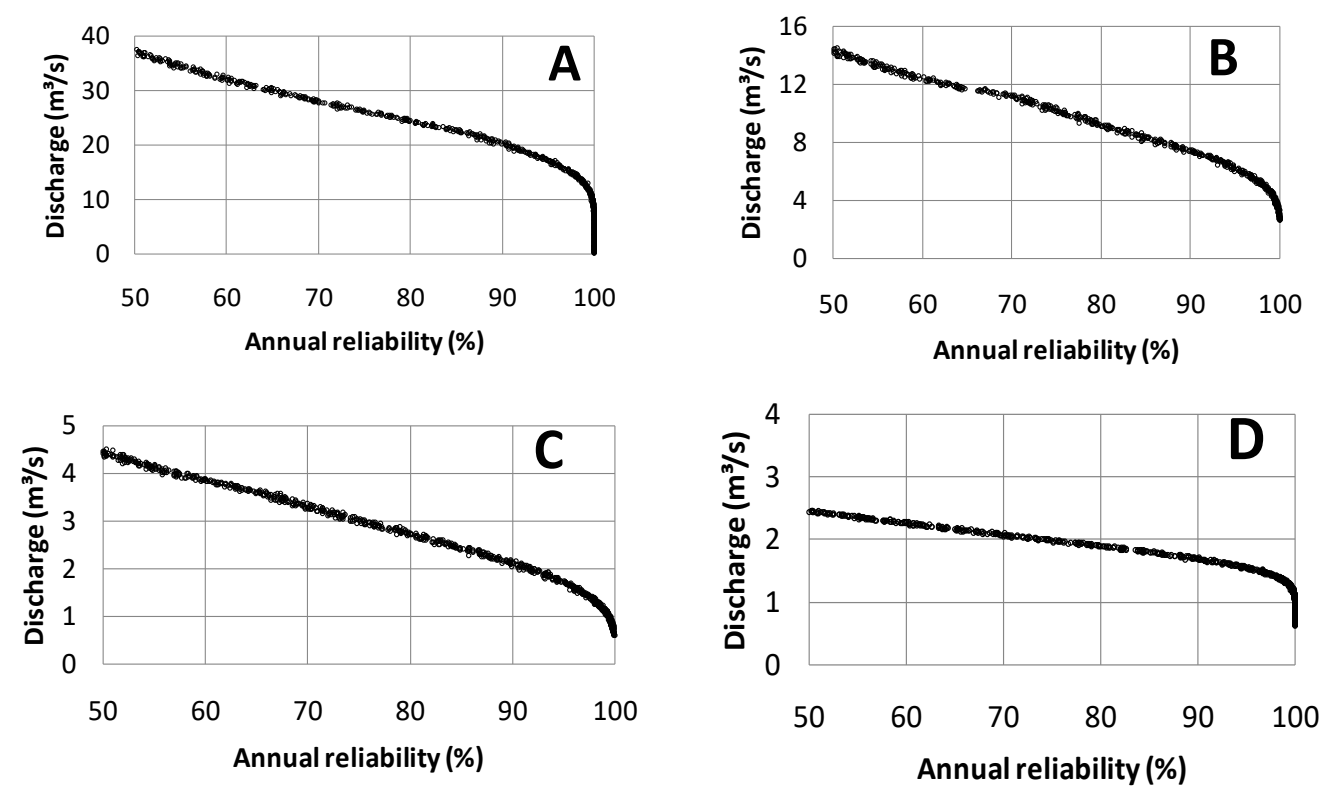

Figure 3. Withdrawal discharge as a function of the annual reliability level for the focus reservoirs: (A) Orós; (B) Araras; (C) Pentecoste; and (D) Aracoiaba.

\subsection{Released Discharges as a Function of the Reservoir Volumes}

The field data (Figure 4) evince that there is a declining-demand trend when the stored volume is high. At the other extreme, when the stored volume decreases below $25 \%$ of the reservoir capacity, the withdrawal discharges also decrease. In Figure 4 and Table 1, it is clear that the optimal $\mathrm{T}$ value (for null $Q_{i}$ and $V_{f}$ ) for the focus reservoirs lies close to six months for all cases (ranging from 5.7 to 6.0 months). The boxes inside the plots (Figure 4) show that the highest-risk discharges (i.e., those of the most external points) are usually released when the reservoir volumes lie between $5 \%$ and $25 \%$ of the storage capacity.

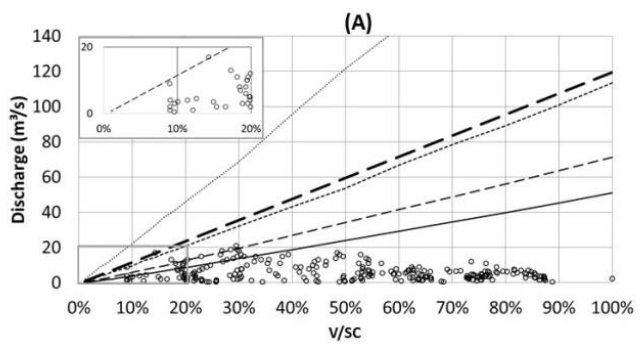

(c)

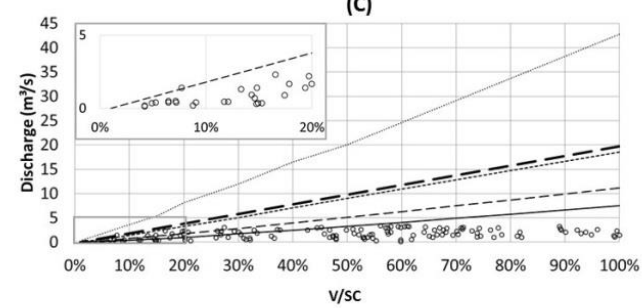

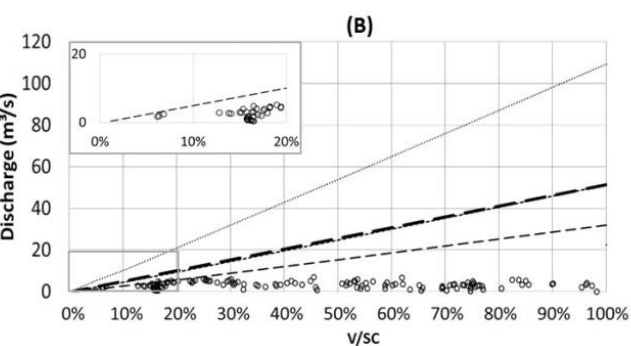

(D)

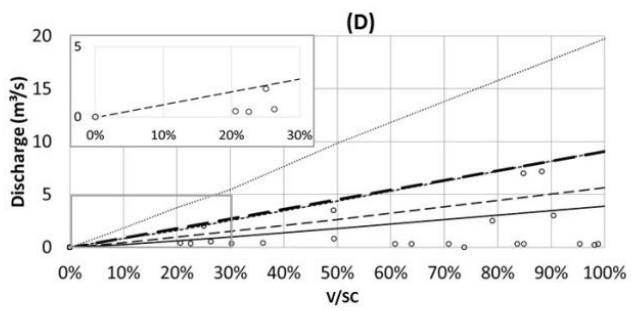

Figure 4. Field data (dots) and simulation (lines) of released discharges as a function of the reservoir volumes (V) divided by the storage capacities (SC) for several values of depletion duration (T). The continuous black line refers to $\mathrm{T}=12$ months; the dashed line to $\mathrm{T}=9$ months; the dotted line to $\mathrm{T}=6$ months; and the continuous grey line to $\mathrm{T}=3$ months. The bold dashed line refers to the calibrated depletion duration $\mathrm{T}$, as described in Section 2.5. The small box on the top right zooms the optimal curve and the field data near the most external point: (A) Orós; (B) Araras; (C) Pentecoste; and (D) Aracoiaba. 


\subsection{Simulations for the Focus Reservoirs}

Table 2 presents the final results of the simulations for the focus reservoirs. On average, water rationing should start when the reservoir stores $20 \%$ of its capacity for very low priority uses ( $80 \%$ annual reliability); $17 \%$ for moderate priority uses (90\% reliability); and $11 \%$ for very high priority uses (99\% reliability), such as human and animal supply.

Table 2. Example of simulation. Withdrawal discharges $\left(\mathrm{Q}_{\mathrm{W}}\right.$, in $\left.\mathrm{m}^{3} / \mathrm{s}\right)$ and the ratio between alert volume (Va) and the storage capacity (SC) for the focus reservoirs, considering five water-use priorities and their respective annual supply reliability. Simulation parameters consider reservoir completely dry-out $\left(\mathrm{V}_{\mathrm{f}}=0\right)$ and no inflow $\left(\mathrm{Q}_{\mathrm{i}}=0\right)$ during six months $(\mathrm{T}=6$ months).

\begin{tabular}{|c|c|c|c|c|c|c|c|c|c|c|}
\hline \multirow{2}{*}{ Water Use } & \multirow{2}{*}{$\begin{array}{l}\text { Water-Use } \\
\text { Priority }\end{array}$} & \multirow{2}{*}{$\begin{array}{l}\text { Water-Use } \\
\text { Reliability }\end{array}$} & \multicolumn{2}{|c|}{ Orós } & \multicolumn{2}{|c|}{ Araras } & \multicolumn{2}{|c|}{ Pentecoste } & \multicolumn{2}{|c|}{ Aracoiaba } \\
\hline & & & $\mathbf{Q}_{\mathrm{W}}$ & $\mathrm{Va} / \mathrm{SC}$ & $\mathrm{Q}_{\mathrm{W}}$ & $\mathrm{Va} / \mathrm{SC}$ & $\mathbf{Q}_{\mathrm{W}}$ & $\mathrm{Va} / \mathrm{SC}$ & $\mathrm{Q}_{\mathrm{W}}$ & $\mathrm{Va} / \mathrm{SC}$ \\
\hline $\begin{array}{l}\text { Temporary- } \\
\text { culture } \\
\text { irrigation }\end{array}$ & Very low & $80 \%$ & 24.35 & 0.23 & 9.12 & 0.19 & 2.71 & 0.17 & 1.89 & 0.23 \\
\hline $\begin{array}{l}\text { Aquaculture } \\
\text { and similar }\end{array}$ & Low & $85 \%$ & 22.74 & 0.21 & 8.36 & 0.17 & 2.46 & 0.15 & 1.81 & 0.22 \\
\hline $\begin{array}{l}\text { Permanent- } \\
\text { culture } \\
\text { irrigation }\end{array}$ & Moderate & $90 \%$ & 20.55 & 0.19 & 7.35 & 0.15 & 2.06 & 0.13 & 1.65 & 0.20 \\
\hline $\begin{array}{l}\text { Industries } \\
\text { and energy } \\
\text { provision }\end{array}$ & High & $95 \%$ & 17.09 & 0.16 & 6.16 & 0.13 & 1.72 & 0.11 & 1.54 & 0.19 \\
\hline $\begin{array}{l}\text { Human and } \\
\text { animal } \\
\text { supply }\end{array}$ & $\begin{array}{l}\text { Very } \\
\text { high }\end{array}$ & $99 \%$ & 9.57 & 0.10 & 4.61 & 0.10 & 1.15 & 0.08 & 1.32 & 0.16 \\
\hline
\end{tabular}

\section{Discussion}

The fact that the derivative $\mathrm{dQ}_{\mathrm{W}} / \mathrm{d}_{\mathrm{G}}$ increases with reliability level means that, to obtain small increments of high-reliability levels, the withdrawal discharge must be considerably reduced. This is an important feature for decision making in systems designed to supply for high-reliability demands, such as human provision. In Brazil, the annual reliability discharge of $90 \%\left(Q_{90}\right)$ is commonly used for water resource planning and can be interpreted as the reference water availability of the reservoir [32]. Recio-Villa et al. [12] also used the annual reliability as a key parameter to establish the reference water availability. However, the authors op cit. recommended a lower reliability level (75\%) for operation of a reservoir located in a humid tropical basin. The largest reservoir, Orós, is capable of yielding $Q_{90}$ over $20 \mathrm{~m}^{3} / \mathrm{s}$ (Table 2), whereas the smallest dam, Aracoiaba, yields less than $2 \mathrm{~m}^{3} / \mathrm{s}$ with the same reliability. Figure 3 and Table 1 indicate that $Q_{90}$ is, on average, only $42 \%$ of the inflow, which means that $58 \%$ of the inflow either evaporates or overflows through the spillway. In fact, hydrological losses are much higher in a semiarid environment than in other climatic zones, including tropical wet basins, due to excessive evaporation and high variation coefficients of the annual inflow to the reservoirs, which leads to considerable outflow during wet years. De Araújo and Piedra [33] compared water availability in two meso-scale basins: one semiarid (in Brazil) and one wet (in Cuba). The results showed that, although the average precipitation in the wet basin was only twice that of the semiarid one, the first had a water availability of $280 \mathrm{~mm} \cdot$ year $^{-1}$ against $20 \mathrm{~mm} \cdot$ year $^{-1}$ in the latter. Another aspect that has to be considered is the effect of the inter-annual hydrological variability [6]. For example, the $\mathrm{Q}_{90}$ of the Pentecoste dam is only 20\% higher than that of Aracoiaba, although the Pentecoste storage capacity is double and its catchment area is five times as big as the one of Aracoiaba. This occurs because the hydrological variability of the Pentecoste basin (coefficient of variation of annual inflow 1.0) is considerably higher than that of Aracoiaba (0.6). The difference 
of the hydrological variability between both basins is mainly due to their respective upper basin morphologies. In Pentecoste, located in the dry hinterlands, the upper-basin terrain slopes are mild (typically below 20\%), the air is dry and temperatures are high, whereas, in the upper Aracoiaba basin, located in higher altitude, the terrain is steeper, air moisture is higher and temperatures are lower. These features determine evaporation losses, as well as the initial runoff conditions, as investigated by De Figueiredo et al. [34].

The declining-demand trend when the stored volume is high means that demand decreases as the stored volume increases above a threshold value (around 50\%), and so do the withdrawal discharges, due to the relative abundance of water from other sources in the basin, such as cisterns, ponds and wells [14]. However, the demand depletion for low stored volume is due to another reason: in that case, despite water scarcity in the basin, the stakeholders fear the lack of water in the near future. In fact, drought experiences strongly affect people emotionally [35], culturally [36] and socially [37-39]. A possible explanation for the optimal duration to be six months is its similarity with the length of the dry season, i.e., the stakeholders try to use the available water as rationally as possible before the next rainy season. Considering the differences in the catchment areas of the reservoirs (size, precipitation, and runoff), the constancy of the optimal $\mathrm{T}$ value suggests that it is representative of the committees located in the Brazilian Semiarid region. Concerning the highest-risk discharges (see the boxes in Figure 4), we noticed that, in the Araras and Pentecoste reservoirs, this limit is low (below 10\% of the storage capacity), showing that their stakeholders are willing to take higher risks concerning the water supply of the following year. In the Orós and Aracoiaba reservoirs, observations differed (15\% and $25 \%$, respectively). The more conservative policy in Orós is probably due to the dam's relevance for the regional water supply. In fact, it is a central supplier to other regions in the State within the drought-relief policies [28]. The Orós operation is, therefore, decided not only by direct water users, but also by the Management Company, which plans the water policy for the State as a whole. The Aracoiaba dam is the least vulnerable reservoir among those investigated in this research: it has the highest (2.38 years) average residence time (i.e., the ratio between the storage capacity and the average inflow), which is $50 \%$ higher than the average of the remaining reservoirs. It also counts on the highest precipitation $\left(828 \mathrm{~mm} \cdot\right.$ year $\left.^{-1}\right)$ and the highest $(76 \%)$ hydrologic efficiency ( $\mathrm{Q}_{90} /$ average inflow, Table 1; see also [33]). This means that the Aracoiaba reservoir rarely dries out, and its stakeholders fear extreme scarcity already when the stored volume is $25 \%$ of its capacity (against $15 \%$ in Orós, $7 \%$ in Araras, and 8\% in Pentecoste). In Table 2, it is noticeable that Aracoiaba presents the highest relative alert volumes.

According to the Brazilian National Water Law (BRAZIL, 1997), some water uses should have priority when it comes to water access during water-scarcity occasions. We assumed, hence, several (five) priority levels among the water uses, and associated an annual reliability to each priority, simulating a possible result from a committee decision meeting (Table 2). After six years of hydrological drought, on 23 January 2018, Orós had 6\% of its storage capacity, Araras 7\%, Pentecoste less than 1\%, and Aracoiaba 15\% [29]. Considering the results of Table 2, on this date, all studied reservoirs should rationalize water even for very high priority uses, which has not occurred thus far. Another important issue is the decision on how much water should be rationalized for each water use in each situation. The hierarchical water-reliability policy, although necessary and helpful, is also a source of conflicts. Take, for example, the case of Orós reservoir at $20 \%$ of its capacity. Very low and low priority users will have to save water, but they will struggle to get as much as possible, whereas higher priority users will try to release as little as possible to delay (or even avoid) having to rationalize water themselves [10]. An even worse scenario is that in which all users have to suffer supply restriction. By how much should each use be reduced? Should rationalization be linear with the licensed discharge? Another gap — still to be developed within the model framework — is the consideration of water quality [27] as a key parameter in the decision making. These problems are still technically unsolved, but a democratic and representative basin committee seems to be the best forum to decide such matters and provide proper water governance in reservoir-dependent regions [40]. 


\section{Conclusions}

We introduce a novel and hydrologically-sound method to provide a simple relation between classes of water uses and their respective alert volumes. The method uses a new approach and considers the input from committee stakeholders to classify water uses and to associate them with the annual reliability level. Hydrological models associate withdrawal discharges with both the reliability level and the alert volume. Our method was applied to four important reservoirs $\left(2 \times 10^{2}-2 \times 10^{3} \mathrm{hm}^{3}\right)$ of the Brazilian Semiarid region. The results indicate that uses with very low priority should start rationalization when the reservoir volume is, on average, below $20 \%$, whereas uses with very high priority should start rationalization when the reservoir volume is below $11 \%$. It was observed that, after six years of hydrological drought, all users of the focus reservoirs should be under water rationalization, but this has not happened until now. The field data show that, when the stored reservoir volume is higher than $50 \%$, demand decreases because of the relative abundance of water from other sources in the basin. When the stored volumes are low (typically below 25\%), the withdrawal discharges also decrease, most likely due to the fear of water scarcity in the near future. The field data also give evidence that the highest-risk discharges (i.e., those of the most external points) are usually released when the reservoir volumes lie between $5 \%$ and $25 \%$ of the storage capacity. Despite the water-priority policy's relevance, it is also a source of conflicts, with no technical solution. However, a democratic and representative committee seems to be the best forum to decide such matters. The here-derived guidelines are simple and should help to enhance water governance among the less educated stakeholders (in terms of hydrological modeling) in water-scarce and reservoir-dependent regions.

Author Contributions: Conceptualization, J.C.d.A.; methodology, J.C.d.A. and G.L.M.; validation, J.C.d.A., G.L.M. and B.P.d.L.; formal analysis, J.C.d.A. and G.L.M.; investigation, J.C.d.A.; data curation, J.C.d.A., G.L.M. and B.P.d.L.; writing-original draft preparation, J.C.d.A.; writing—review and editing, G.L.M.; and funding acquisition, J.C.d.A.

Funding: This research was funded by CNPq-Brazilian National Research Council (grant numbers 407999/16-7; 301677/15-8).

Acknowledgments: We acknowledge the support given by CAPES (Coordenação de Aperfeiçoamento de Pessoal de Nivel Superior), from the Brazilian Ministry of Education.

Conflicts of Interest: The authors declare no conflict of interest.

\section{References}

1. Gaiser, T.; Krol, M.; Frischkorn, H.; de Araújo, J.C. Global Change and Regional Impacts; Springer: Berlin, Germany, 2003; ISBN 978-3-540-43824-3.

2. Mamede, G.L.; Araújo, N.; Schneider, C.M.; de Araújo, J.C.; Herrmann, H.J. Overspill avalanching in a dense reservoir network. Proc. Natl. Acad. Sci. USA 2012, 109, 7191-7195. [CrossRef] [PubMed]

3. Peter, S.; de Araújo, J.C.; Araújo, N.; Herrmann, H. Flood avalanches in a semiarid basin with a dense reservoir network. J. Hydrol. 2014, 512, 408-420. [CrossRef]

4. Paranage, K. Understanding the relationship between water infrastructure and socio-political configurations: A case study from Sri Lanka. Water 2018, 10, 1402. [CrossRef]

5. Song, W.; Yuan, Y.; Jiang, Y.; Lei, X.; Shu, D. Rule-based water resource allocation in the Central Guizhou Province, China. Ecol. Eng. 2016, 87, 194-202. [CrossRef]

6. Chen, K.; Guo, S.; He, S.; Xu, T.; Zhong, Y.; Sun, S. The value of hydrologic information in reservoir outflow decision-making. Water 2018, 10, 1372. [CrossRef]

7. Tan, Q.; Wang, X.; Wang, H.; Wang, C.; Lei, X.; Xiong, Y.; Zhang, W. Derivation of optimal joint operating rules for multi-purpose multi-reservoir water-supply system. J. Hydrol. 2017, 551, 253-264. [CrossRef]

8. Yan, D.; Ludwig, F.; Huang, H.Q.; Werners, S.E. Many-objective robust decision making for water allocation under climate change. Sci. Total Environ. 2017, 607-608, 294-303. [CrossRef] [PubMed]

9. Sangiorgio, M.; Guariso, G. NN-Based implicit stochastic optimization of multi-reservoir systems management. Water 2018, 10, 303. [CrossRef] 
10. Bhatia, N.; Srivastav, R.; Srinivasan, K. Season-dependent hedging policies for reservoir operation-a comparison study. Water 2018, 10, 1311. [CrossRef]

11. Tian, Y.; Xiong, J.; He, X.; Pi, X.; Jiang, S.; Han, F.; Zheng, Y. Joint operation of surface water and groundwater reservoirs to address water conflicts in arid regions: An integrated modeling study. Water 2018, 10, 1105. [CrossRef]

12. Recio-Villa, I.; Martínez Rodríguez, J.B.; Molina, J.L.; Pino Tarragó, J.C. Multiobjective optimization modeling approach for multipurpose single reservoir operation. Water 2018, 10, 427. [CrossRef]

13. BRAZIL. Law No 9 433, from 8 January 1997. Brasília. Available online: http://www.planalto.gov.br/ccivil_ 03/LEIS/L9433.htm (accessed on 1 September 2018).

14. De Araújo, J.C.; Bronstert, A. A method to assess hydrological drought in semiarid environments and its application to the Jaguaribe River basin, Brazil. Water Int. 2016, 41, 213-230. [CrossRef]

15. Telles Melo, J.A.; Montezuma, T.F.; Marques, G.O.P. Direito à Água e Injustiça Hídrica: Um Estudo Sobre a (In)Constitucionalidade dos Benefícios Tarifários às Indústrias Hidrointensivas no Complexo Industrial do Pecém. 2017. Available online: http:/ / www.planetaverde.org/arquivos/biblioteca/arquivo_ 20170605175106_890.pdf (accessed on 1 September 2018).

16. Liu, P.; Li, L.; Chen, G.; Rheinheimer, D.E. Parameter uncertainty analysis of reservoir operating rules based on implicit stochastic optimization. J. Hydrol. 2014, 514, 102-113. [CrossRef]

17. Feng, M.; Liu, P.; Guo, S.; Gui, Z.; Zhang, X.; Zhang, W.; Xiong, L. Identifying changing patterns of reservoir operating rules under various inflow alteration scenarios. Adv. Water Resour. 2017, 104, 23-36. [CrossRef]

18. Andreu, J.; Capilla, J.; Sanchis, E. A generalized decision-support system for water-resources planning and operational management. J. Hydrol. 1996, 177, 269-291. [CrossRef]

19. Porto, R.L.L.; Azevedo, L.G.T. Sistemas de Suporte a Decisões de Recursos Hídricos. In Técnicas Quantitativas Para o Gerenciamento de Recursos Hídrico; ABRH: Porto Alegre, Brazil, 1997. (In Portuguese)

20. Zagona, E.; Fulp, T.J.; Shane, R.; Magee, T.; Goranflo, H.M. RiverWare: A generalized tool for complex reservoir system modeling. J. Am. Water Resour. Assoc. 2001, 37, 913-929. [CrossRef]

21. Labadie, J. MODSIM: River Basin Management Decision Support System. In Watershed Models; CRC Press: Boca Raton, FL, USA, 2005.

22. Li, M.; Fu, Q.; Singh, V.P.; Liu, D. An interval multi-objective programming model for irrigation water allocation under uncertainty. Agric. Water Manag. 2018, 196, 24-36. [CrossRef]

23. Alexandre, D.M.B. Gestão de Pequenos Sistemas Hídricos No Semiárido Nordestino. Ph.D. Thesis, Federal University of Ceará, Fortaleza, Brazil, July 2012.

24. Basco-Carrera, L.; Warren, A.; van Beek, E.; Jonoski, A.; Giardino, A. Collaborative modelling or participatory modelling? A framework for water resources management. Environ. Model. Softw. 2017, 95-110. [CrossRef]

25. Halbe, J.; Pahl-Wostl, C.; Adamowski, J. A methodological framework to support the initiation, design and institutionalization of participatory modeling processes in water resources management. J. Hydrol. 2018, 556, 701-716. [CrossRef]

26. Zhang, S.; Foerster, S.; Medeiros, P.; de Araújo, J.C.; Motagh, M.; Waske, B. Bathymetric survey of water reservoirs in north-eastern Brazil based on TanDEM-X satellite data. Sci. Total Environ. 2016, 571, 575-593. [CrossRef] [PubMed]

27. Coelho, C.F.; Heim, B.; Foerster, S.; Brosinsky, A.; de Araújo, J.C. In situ and satellite observation of CDOM and chlorophyll-a dynamics in small water surface reservoirs in the Brazilian Semiarid Region. Water 2017, 9, 913. [CrossRef]

28. Campos, J.N.B. Paradigms and public policies on drought in Northeast Brazil: A historical perspective. Environ. Manag. 2015, 55, 1052-1063. [CrossRef] [PubMed]

29. CEARÁ. Electronic Atlas of Water Resources of Ceará. 2018. Available online: http://atlas.srh.ce.gov.br/ (accessed on 23 January 2018).

30. COGERH-Companhia de Gestão dos Recursos Hídricos. Available online: https:/ / www.cogerh.com.br/ (accessed on 3 January 2018).

31. De Araújo, J.C.; Güntner, A.; Bronstert, A. Loss of reservoir volume by sediment deposition and its impact on water availability in semiarid Brazil. Hydrol. Sci. J. Sci. Hydrol. 2006, 51, 157-170. [CrossRef]

32. Campos, J.N.B. Modeling the yield evaporation spill in the reservoir storage process: The regulation triangle diagram. Water Resour. Manag. 2010, 24, 3487-3511. [CrossRef] 
33. De Araújo, J.C.; Piedra, J.I.G. Comparative hydrology: Analysis of a semiarid and a humid tropical watershed. Hydrol. Process. 2009, 23, 1169-1178. [CrossRef]

34. De Figueiredo, J.V.; de Araújo, J.C.; Medeiros, P.H.A.; Costa, A.C. Runoff initiation in a preserved semiarid Caatinga small watershed, Northeastern Brazil. Hydrol. Process. 2016, 30, 2390-2400. [CrossRef]

35. Keshavarz, M.; Karami, E.; Vanclay, F. The social experience of drought in rural Iran. Land Use Policy 2013, 30, 120-129. [CrossRef]

36. Xi, J. Types of integration and depressive symptoms: A latent class analysis on the resettled population for the Three Gorges dam project, China. Soc. Sci. Med. 2016, 157, 78-86. [CrossRef] [PubMed]

37. Keilty, K.; Beckley, T.M.; Sherren, K. Baselines of acceptability and generational change on the Mactaquac hydroelectric dam headpond (New Brunswick, Canada). Geoforum 2016, 75, 234-248. [CrossRef]

38. Wilhite, D.A.; Svoboda, M.D.; Hayes, M.J. Understanding the complex impacts of drought: A key to enhancing drought mitigation and preparedness. Water Resour. Manag. 2007, 21, 763-774. [CrossRef]

39. Sivapalan, M. From engineering hydrology to Earth system science: Milestones in the transformation of hydrologic science. Hydrol. Earth Syst. Sci. 2018, 22, 1665-1693. [CrossRef]

40. Singer, J.; Pham, H.T.; Hoang, H. Broadening stakeholder participation to improve outcomes for dam-forced resettlement in Vietnam. Water Resour. Rural Dev. 2014, 4, 85-103. [CrossRef]

(C) 2018 by the authors. Licensee MDPI, Basel, Switzerland. This article is an open access article distributed under the terms and conditions of the Creative Commons Attribution (CC BY) license (http:/ / creativecommons.org/licenses/by/4.0/). 